\section{Training for internal medicine}

I read with amusement the proposal to increase by one year the training for internal medicine specialists. ${ }^{1}$ Does everybody today want to be known as having a "special skill"?

I submit that if residents who complete four years of training in internal medicine find themselves lacking skills, it is the training that is deficient, not the time spent training. Four years is a substantial amount of time and clearly should suffice for becoming a general internist - of which, incidentally, we have too few. Most residents subspecialize and then, over time, lose the skills necessary to view the patient as a whole.

Increasing training by one year will do very little to address a deficient program or the shortage of general internists. It merely keeps students in school for one more unnecessary year.

\section{Ana M. Porzecanski MD \\ Retired}

\section{REFERENCE}

1. Vogel L. Internal bickering over internal subspecialty. CMAJ 2010;182:1287-8.

For the full letter, go to: www.cmaj.ca/cgi/eletters/182/12/1287\#595910

DOI: $10.1503 / \mathrm{cmaj} .110-2124$

\section{Vitamin D for mental health and cognition}

Hanley and colleagues have written an excellent article. ${ }^{1}$ Further, vitamin D and receptors have been increasingly implicated in the pathology of cognition and mental illness. Vitamin D activates receptors on neurons in regions implicated in the regulation of behaviour, stimulates neurotrophin release and protects the brain by buffering antioxidant and anti-inflammatory defences against vascular injury. ${ }^{2}$ There is growing evidence for a relationship between vitamin $\mathrm{D}$ receptors in the brain, hypovitaminosis D and abnormal executive cognitive functions, ${ }^{3,4}$ major depression, ${ }^{5}$ bipolar dis$\operatorname{order}^{6}$ and schizophrenia.
Further studies are needed to investigate the impact of vitamin D supplementation on cognition, mood disorders and schizophrenia. Given current evidence, ensuring normal vitamin $\mathrm{D}$ levels may be critical for prevention and treatment in people at high risk of mental and cognitive illness and for treatment in those for whom mental illness has already been diagnosed.

\section{Serdar M. Durson MD PhD}

Professor of psychiatry and neuroscience, University of Alberta, Edmonton, Alta.

\section{REFERENCES}

1. Hanley DA, Cranney A, Jones G, et al. Vitamin D in adult health and disease: a review and guideline statement from Osteoporosis Canada. CMAJ 2010;182:1315-19.

2. Cherniack EP, Troen BR, Florez HJ, et al. Some new food for thought: the role of vitamin D in the mental health of older adults. Curr Psychiatry Rep 2009;11:12-9.

3. Grecksch G, Rüthrich H, Höllt V, et al. Transient prenatal vitamin D deficiency is associated with changes of synaptic plasticity in the dentate gyrus in adult rats. Psychoneuroendocrinology 2009; 34(suppl 1):S258-64.

4. Pogge E. Vitamin D and Alzheimer's disease: is there a link? Consult Pharm 2010;25:440-50.

5. Lee DM, ajar A, O'Neill TW, et al. Lower vitamin D levels are associated with depression among community-dwelling European men. J Psychopharmacol 2010; Sept. 7 [Epub ahead of print].

6. Yan J, Feng J, Craddock N, et al. Vitamin D receptor variants in 192 patients with schizophrenia and other psychiatric diseases. Neurosci Lett 2005;380: 37-41.

7. McGrath JJ, Burne TH, Féron F, et al. Developmental vitamin D deficiency and risk of schizophrenia: a 10-year update. Schizophr Bull 2010;36:1073-8

DOI: $10.1503 / \mathrm{cmaj} .110-2125$

\section{Decriminalize prostituted women}

It is inaccurate to describe prostitution as a legal activity in Canada. It is an activity that is criminally prohibited indirectly rather than directly, making it illegal in almost all instances.

Shannon ${ }^{1}$ treats decriminalization as monolithic, when in fact Sweden and other Nordic countries have decriminalized prostituted persons, who are overwhelmingly women, while continuing to criminalize johns and pimps. Women are also offered support to find other sources of income, something most women in prostitution say they want. This approach, which has been quite successful in reduc- ing trafficking and sexual exploitation, ought to be adopted in Canada.

Janine L. Benedet

Associate professor, Faculty of Law,

University of British Columbia,

Vancouver, BC

\section{REFERENCE}

1. Shannon K. The hypocrisy of Canada's prostitution legislation. CMAJ 2010;182:1388.

DOI: $10.1503 / \mathrm{cmaj} .110-2126$

\section{Flipside of the dialysis argument}

Although I don't have the expertise to take a position in the debate about chronic cerebrospinal venous insufficiency, Stanbrook and Hébert's aside about the common finding of venous stenosis in patients receiving dialysis ${ }^{1}$ lends itself to a corollary. Since venous angioplasty of stenosed dialysis access veins is a common procedure with a low rate of complication, it is somewhat disingenuous for those railing against Zamboni's treatment ${ }^{2}$ to claim that it is new, unproven or potentially dangerous.

\section{Mark DeSoto}

Toronto, Ont.

\section{REFERENCES}

1. Stanbrook MB, Hébert PC. Access to treatment for multiple sclerosis must be based on science, not hope. CMAJ 2010;182:1151.

2. Zamboni P, Galeotti R, Menegatti E, et al. A prospective open-label study of endovascular treatment of chronic cerebrospinal venous insufficiency. J Vasc Surg 2009;50:1348-58.

DOI: $10.1503 / \mathrm{cmaj} .110-2127$

\section{Correction: Clinical guidelines}

In the letter "Clinical guidelines may need ethical component," the first author's name was misspelled. The name should have appeared as W. GöttgensJansen. CMAJ regrests any inconvenience this error may have caused.

\section{REFERENCE}

1. Göttgens-Jansen W, van Leeuwen E, De Smet $\mathrm{PAGH}$, et al. Clinical guidelines may need ethical component. CMAJ 2010;182(14):1546-7.

DOI: $10.1503 / \mathrm{cmaj} .110-2123$ 